\title{
Inaugural ceremony of the Independent Commission on International Humanitarian Issues
}

The inaugural ceremony of the Independent Commission on International Humanitarian Issues took place on Tuesday, 5 July, at the Palais des Nations in Geneva, under the chairmanship of Prince Sadruddin Aga Khan, former United Nations High Commissioner for Refugees, and in the presence of numerous guests, including the United Nations Secretary-General. The Red Cross was represented by Mr. Pestalozzi, Vice-President of the ICRC, members of the ICRC administration and of the League Secretariat.

This Commission was created in response to the proposal by Crown Prince Hassan ben Talal of Jordan for a "New International Humanitarian Order", and following a regional seminar organized jointly by the ICRC and the Jordan National Red Crescent Society in Amman, in April 1981, on the dissemination of knowledge of international humanitarian law.

The members of the Commission include some twenty-five persons of high repute in political, legal and academic circles, all committed to the humanitarian cause. They come from all parts of the world: Oceania, Europe and Africa, the Americas, the Near East and Asia. Among them, Mr. Henrik Beer, Secretary General Emeritus of the League of Red Cross Societies, will be well-known to our readers.

A few days after the inaugural ceremony, the Commission met in the premises of the Henry Dunant Institute to define its goals and working methods. It elected two co-chairmen, Prince Sadruddin Aga Khan and Prince Hassan of Jordan; it planned to meet two to three times a year for a period of three years, after which it would probably be dissolved; the subjects it chooses to study will be entrusted to experts who will report back to the Commission. The first subjects proposed are: Desertification; Persons without protection; Application of humanitarian rules in time of armed conflict. 
The inaugural ceremony opened with a short speech by Prince Sadruddin Aga Khan:

"We are assembled here today to inaugurate the Independent Commission on International Humanitarian Issues. In my capacity as convenor, it is my pleasure and privilege to welcome you all most warmly to this ceremony.

It is gratifying to see so many eminent persons from all parts of the world... Their presence is an eloquent manifestation of a shared concern for the increasingly vulnerable and exposed position of the individual in contemporary society.

At a time when most discussions are centered around politics and economics, military strategies and ideological postures, it is surely significant that we should get together to discuss humanitarian issues...

We are thankful to the Government of Switzerland for its generous offer of assistance in the establishment of the Secretariat of the Commission. The choice of Geneva as the seat of this Commission is in keeping with the well-established tradition of this city, which already serves as headquarters of so many international humanitarian agencies, both governmental and non-governmental.

Although the inaugural ceremony is taking place in this chamber of the United Nations, I wish to stress that the Independent Commission will be functioning outside the framework of the United Nations. It would, however, seek to benefit from the experience already gained by its relevant agencies. We sincerely hope that our work will further strengthen their efforts...

The actual meeting of the Commission will take place tomorrow at the Henry Dunant Institute. It is a befitting tribute to a great man and a noble endeavour which the movement of the Red Cross represents."

Mr. Raymond Probst, Secretary of State for the Swiss Federal Department of Foreign Affairs, spoke to the assembly on behalf of Switzerland, host country of the Independent Commission.

"It is my honour to welcome, on behalf of the Government of Switzerland, the members of this esteemed assembly, which has met here today to inaugurate the work of the Independent Commission on International Humanitarian Issues...

I believe I am correct in stating that never before has there been a gathering of such eminent personalities, with such high responsibilities and great experience in humanitarian, political, legal or scientific fields, 
to discuss humanitarian issues. My country is pleased to host such a distinguished assembly, and will observe its progress with the utmost interest. It is happy to have been able to facilitate the Commission's work by assisting with the practical arrangements, in accordance with its tradition of hospitality and its humanitarian vocation.

The choice of Geneva for the Secretariat of the Commission and for its meetings most certainly reflects the Members' desire for their analyses of humanitarian problems to be carried out near to most of the international bodies working to aid those in distress around the world... It is also in Geneva, as we know, that the instruments of international law relative to the protection of victims of armed conflicts have been adopted since 1864, and it is my wish that, when the Commission reviews the instruments of international law currently in force in the humanitarian field, it may emphatically reiterate the obligatory character of the rules they set forth. This is desirable not only for the standards of international humanitarian law applicable in armed conflicts, but also for the rules concerning the status of refugees and human rights.

The Commission today sets out to accomplish a noble but hard and vast task. Switzerland looks forward to any contribution you can make to solving the humanitarian problems of our times."

The Assembly then listened to the words of Mr. Javier Pérez de Cuéllar, Secretary-General of the United Nations:

"It gives me great satisfaction to speak today on the occasion of the inaugural ceremony of this Commission... I do not need to emphasize to you the enormity of the humanitarian problems facing the international community. Millions of human beings are condemned to a life of poverty and scorn, their basic needs unsatisfied, their fundamental rights denied... Such serious problems must be tackled with an open mind and determined action.

There are, of course, a large number of organizations, programmes and projects which aim to deal with some of these problems, nationally and internationally. However, in spite of these efforts, praiseworthy though they are, and in spite of some constructive reaction on the part of the international community, we cannot remain indifferent to continued and inhumane suffering and poverty. It is this aspect, this dimension of our activities, which we must always bear in mind; indeed, the very dignity of the human being is at issue... 
The United Nations, as we all know, has the historic mission of proclaiming and encouraging the practical application of universallyrecognized standards of human rights. It has also drawn up standards relative to the rights of refugees; it has created bodies to intervene in case of natural or man-made disasters... Finally, and perhaps most importantly, the UN has undertaken an action for peace of inestimable value which, because it directly affects the stability of our planet, is also of an essentially humanitarian nature.

Nor can we forget the activities of other governmental and nongovernmental organisations, which also tackle humanitarian issues and without which the world would be in an even more tragic state. I refer here in particular to the role of the International Committee of the Red Cross and to its efforts to apply international humanitarian law...

I have no doubt that your debate will focus first and foremost on the means of ensuring universal economic development, for it is clear that underdevelopment is the primary cause of human suffering in the world today. The notions of equality, of equity and of social justice, on a national or international scale, are closely linked to those of development. Universal respect for human rights standards as defined by the United Nations, the extension and application of humanitarian rules in armed conflicts and the measures that can be taken by the community of nations to satisfy other pressing needs in the humanitarian field are some of the problems requiring immediate attention...

Allow me, therefore, to express the fervent wish that your work will be successful. Its nature is such that not only will it supplement the work of the United Nations, but it will also help the community of nations to build the better world it has aspired to for such a long time."

Finally, Prince Hassan of Jordan, originator of the Independent Commission, explained how he thought of suggesting that a new international humanilarian order be created, and how the Commission, by concentration on issues not dealt with by any other body and where humanitarian gaps still exist, could contribute to the edification of this new international humanitarian order.

"It is a matter of deep personal satisfaction to me that we should be meeting here today to inaugurate the Independent Commission on International Humanitarian Issues. Its origin is to be found in a proposal I made to the United Nations General Assembly suggesting that member States should endeavour collectively to promote a new inter- 
national humanitarian order... The General Assembly Resolution relating to the order was adopted by consensus. The Assembly adopted, again by consensus, a second resolution which mentioned the proposal relating to the establishment of an Independent Commission...

Some time ago we had an ICRC Conference in Amman. On that occasion, a few of us thought that efforts should be made to develop a universal code of conduct. Discussions at that time helped me crystallize my own thinking regarding the dire need to promote a comprehensive humanitarian framework which covers more adequately the existing gaps in international humanitarian law and practice and deals with issues which are not sufficiently addressed. This may be a challenging and possibly quite frustrating task but it needs to be undertaken. The work of our Commission may hopefully be the beginning of such an undertaking by the international community.

The greatest advantage of the Commission lies in its independence. Its deliberations need not suffer from constraints which usually characterize discussions between governments... We are, of course, conscious of the fact that concrete results and tangible actions are more important than speeches and reports. However, action which is not preceded by careful thought can be more dangerous than no action at all... We see the task of our Commission limited in time and scope. It must address specific, pre-determined areas of humanitarian concern which call for greater attention and care.

We recognize the value of the efforts of international humanitarian agencies, both governmental and non-governmental... I have also witnessed the work of non-governmental organizations such as the International Red Cross, as well as philanthropic bodies and voluntary agencies. I wish to pay tribute to the selfless service they render to millions of people around the globe.

The fact is nonetheless that despite all these noble efforts, the problems these agencies face remain undiminished... The quality of life has steadily degenerated over the past decades. Human rights have, by and large, remained a peripheral issue. Problems of poverty, hunger, illiteracy, uprootedness have not received as much attention as they deserve. The individual human being, the ultimate recipient of all progress, has seen very little come his way in most parts of the world. The overall picture remains grim: we are not adequately prepared for the next century or even the next decade...

We fully realize that the establishment of the Commission may not in itself be a miraculous panacea. However, even if it represents nothing more than a "cry of anguish" by a deeply concerned group of individuals, 
it is worthwhile, for it may increase the awareness of the grave problems our children are going to inherit. In the final analysis, the question to which the Commission may have to seek an answer is this: In the contemporary economic, social and political environment, is it possible for human beings to be more humane?"

\section{Round Table on "Population Movements"}

The International Institute of Humanitarian Law, in San Remo, organized a round table on "Population Movements", which was held in Florence (Italy), from 14 to 18 June 1983.

Over 130 people gathered in Florence, all specialists of various backgrounds: ministers and high-ranking officials from several States, representatives from intergovernmental and non-governmental organizations, experts and in particular university professors. They came from all parts of the world. The Red Cross was also well represented, in particular by members of the Italian Red Cross, the League and the ICRC.

Population movements are currently of considerable concern to the international community. Attention of course is focused on movements, above all involuntary or forced displacements, that present problems. The Institute and in particular its President, Professor Patrnogic, wanted to see these problems examined as a whole, giving equal attention to movements in time of peace-for example, migrant workers-and in time of tension or conflict--refugees and displaced persons-and wished each question to be studied from the point of view both of the individual and of the States.

The President summarized the lively and constructive deba tes in a series of "Final Remarks", the main points of which are as follows:

- Voluntary migratory movements in conditions of peace and security are beneficial to humanity.

- In involuntary migrations, people move to survive, and especially to flee the effects of war, internal disorder or natural disasters, to escape famine or underdevelopment, out of fear of persecution or other violations of human rights. 